\title{
Up Against 'Edutopia': Dr. James Daly's Crusade against the Spectre of Progressive Education, 1968-1983
}

\author{
Paul Bennett \\ Mount Saint Vincent University
}

\section{ABSTRACT:}

Over forty years ago, an Ontario Provincial Committee headed by Emmett Hall and Lloyd Dennis released Living and Learning (1968), a bold and provocative progressive reform prescription for the perceived ills afflicting the Ontario public school system. One of the most strident critics of the Hall-Dennis Report was Dr. James Daly, a little known McMaster University English history professor, who responded with a stinging critique in the form of a political pamphlet-sized book entitled Education or Molasses: A Critical Look at the Hall-Dennis Report (1969). While Daly's little book echoed the essential message of Hilda Neatby's So Little for the Mind (1953), it never attracted the same popular acclaim. Many Ontario educators, from regular classroom teachers to academics sympathized with Daly, but few rallied to his defence in the ensuing public debate. This article explores Dr. Daly's personal crusade and assesses why it fizzled in the public arena, yet actually helped to turn the tide in the 1980s backlash against the Hall-Dennis brand of 'romantic progressive' reform.

\section{RÉSUMÉ:}

Il y a plus de quarante ans, un Comité provincial ontarien dirigé par Emmett Hall et Lloyd Dennis publiait Living and Learning (1968), une réforme audacieuse et provocatrice visant à enrayer les maux affligeant selon eux le système public d'éducation. L'un des détracteurs les plus véhéments du Rapport Hall-Dennis est James Daly, un professeur d'histoire anglaise peu connu de l'Université McMaster, qui publie une réplique cinglante sous la forme d'un pamphlet politique intitulé Education or Molasses : A Critical Look at the Hall-Dennis Report (1969). Bien que son petit livre reprenne l'essentiel du message de So Little for the Mind (1953) de Hilda Neatby, Daly ne recueille pas l'appui populaire de son prédécesseur. Un grand nombre d'éducateurs ontariens, des enseignants et des professeurs d'université sympathisent avec Daly, mais peu se portent à sa défense dans le débat public qui s'ensuit. Cet article explore la croisade personnelle du professeur Daly et son échec dans l'arène publique, ainsi que sa contribution à changer le cours des événements lors de la réaction tardive contre la réforme de Hall-Dennis durant les années 1980 qualifiée alors de réforme "romantique progressive ". 
One fairly ordinary day in the Fall Term of 1968, McMaster historian John H. Trueman handed a young 36-year-old English history professor, James W. Daly, a copy of Living and Learning, the glossy, coffee-table sized report of the Ontario Provincial Committee on Aims and Objectives of Education. Clutching the now

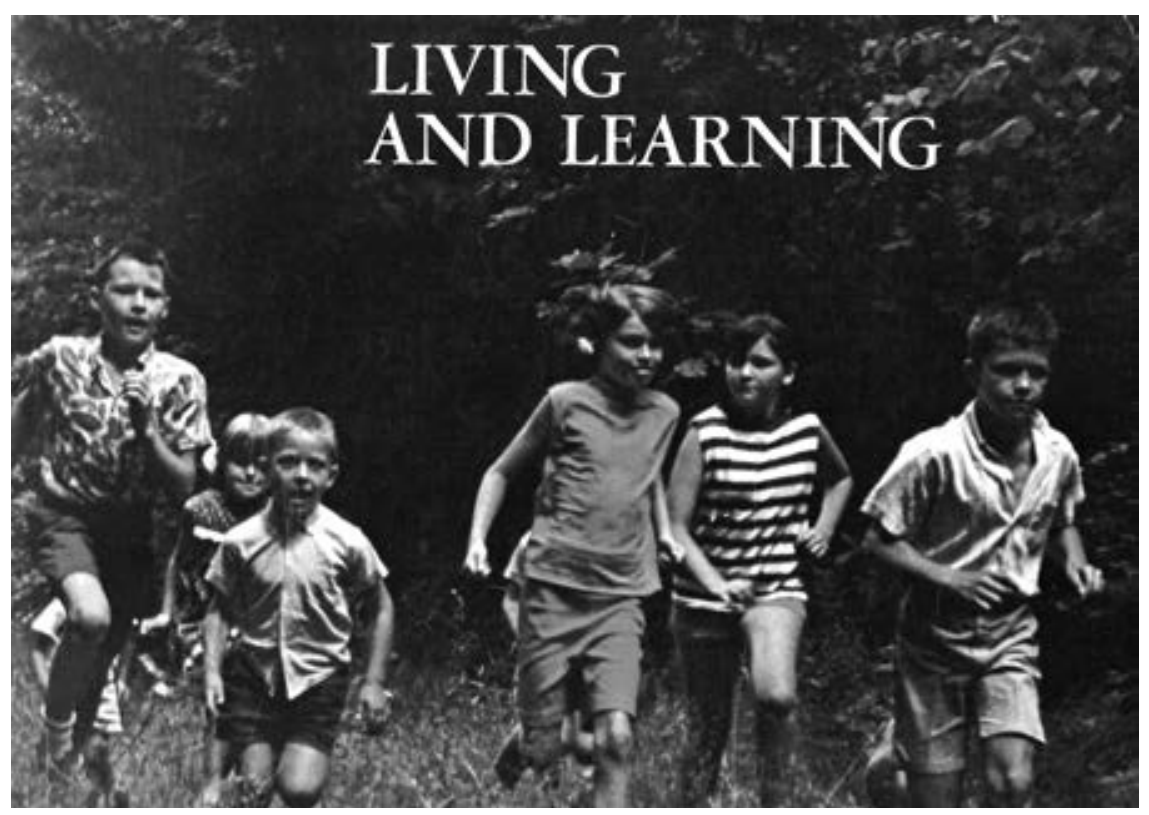

Figure 1: Living and Learning.

infamous Hall-Dennis Report in his hands, for the very first time, Daly went on his way, virtually devouring its contents. Shortly thereafter, he rushed back to Trueman's History Department office and blurted out: "You ought to see this. It's everything we might have feared!" It was that brief encounter which gave rise to Dr. James Daly's little pamphlet, Education or Molasses?, a stinging critique of the Hall-Dennis Report. $^{2}$ It also spurred Daly to launch a personal crusade to expose the fallacies inherent in the Report's unabashed "child-centred philosophy" and to rid the educational world of its deleterious influence.

When it first appeared in June 1968, the Ontario Hall-Dennis Report, named after its co-chairs, Emmett Hall and Lloyd Dennis, was greeted with lavish praise, mostly generated by the Toronto popular media. The Report gave official sanction to a brand of romantic educational progressivism inspired by John Dewey (19591952), the renowned American philosopher, psychologist and educational reformer. Its authors openly embraced core Deweyite principles: the child lies at the heart of "education for a democratic society," learning comes naturally to every child, but schools as institutions "throttle the free flow of individual thought and action." 3 Mimicking Dewey's pedagogic creed, the teacher's primary role was not to teach the subject or to impose certain "habits of mind," but rather to "establish a cheerful, 


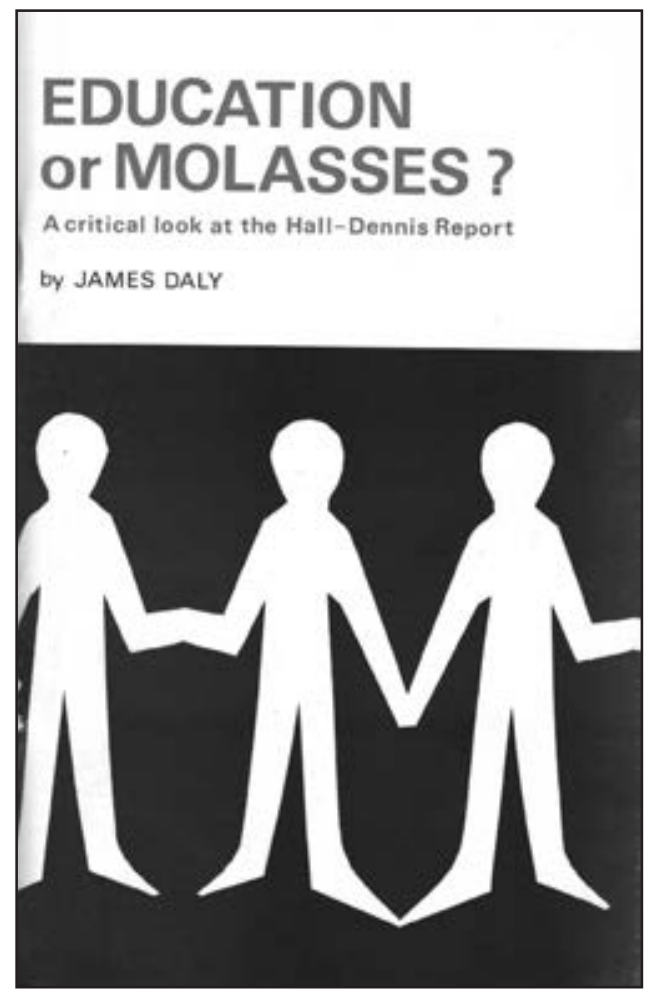

Figure 2: The Critique. One of the most strident critics of the Hall-Dennis Report was Dr. James Daly, a little known McMaster University English history professor, who responded with a stinging critique in the form of a political pamphlet-sized book entitled Education or Molasses: A Critical Look at the Hall-Dennis Report (1969).

social, permissive climate for learning" enabling the child to maintain "creative and democratic relationships." "Unlike previous dry and formalistic government reports, it conveyed a powerful message with catchy slogans such as "the truth shall make us free" and images of smiling children at play in the schools. The attractive and wellpackaged report was so impressive that even Ontario Education Minister William G. Davis was initially swayed by its charms. Even though it was not formally endorsed by the Ontario government, it was essentially the brainchild of Deputy Education Minister J.R. (Jack) McCarthy and his freshly-recruited band of "progressive education" acolytes within the Department. ${ }^{5}$

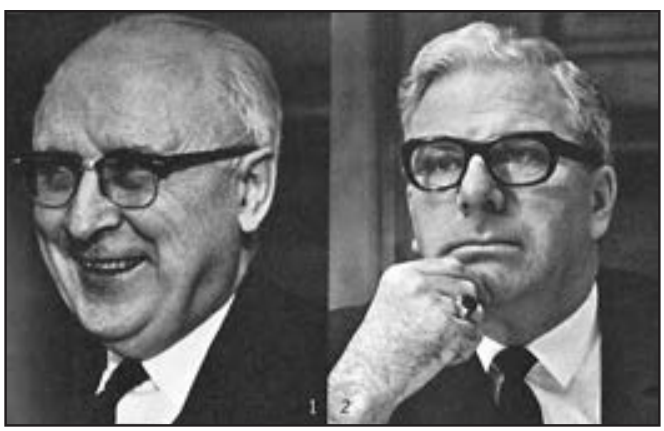

Figure 3: Co-Chairs, Provincial Committee on Aims and Objectives for the Schools of Ontario (1965-68), Emmett Hall and Lloyd Dennis (Government of Ontario). 
After some months, the initial public euphoria began to fade and critical voices started to emerge, especially in academe and among the province's secondary school teachers. Among the first to cast stones were those whom the Ontario educational establishment dismissed as the "carping academic critics." ${ }^{6}$ The second wave was spearheaded by McMaster University’s James W. Daly (1932-1983). His vocal opposition and impressive command of the English language made him almost impossible to ignore. Soon after the appearance of his pamphlet, the tide of public and professional opinion began to turn. Among teachers and so-called "traditionalists" in education, business, and local politics, Daly's book crystallized the gathering forces of resistance against not only the Hall-Dennis version of "Edutopia," but what he lambasted as "the supine acceptance of fashionable piffle." 7

For all of his influence in reshaping the public debate, Professor Daly and his popular "crusade" have been largely overlooked in previous analyses of the rise and fall of Hall-Dennis inspired 'romantic progressive' reform. ${ }^{8}$ The standard history of Ontario's modern educational system, R.D. Gidney's From Hope to Harris, offers a compelling re-interpretation of the Hall-Dennis Report and its legacy, recognizing the profound influence of the Department's eminence gris, J.R. McCarthy, and cutting Lloyd Dennis down to proper size. When it came to discussing the "dissenting voices," Gidney consigned them to a mere footnote. While describing Daly's little book as "one scintillating and scathing jeremiad" that was "not to be missed," he wrote him completely out of the public debate. ${ }^{9}$ Most surprisingly, Canadian history specialist Ken Osborne's 1999 primer entitled Education: A Guide to the Canadian Debate ignores Daly's critique, even though it found considerable support among Ontario secondary school teachers. Indeed, Osborne looked back wistfully on the Report as "the shining star of educational reform" and, without referencing Daly, bemoaned those who "painted" progressivism as "at best woolly-minded idealism and at worst reckless irresponsibility." 10

\section{The Crusading Educational Critic and his Philosophic Conservatism}

Dr. Daly was a most unlikely public critic. Raised and educated in the Ottawa Valley, he was only in his mid-30s when the Report appeared. After teaching at the high school level for three years, he realized that he was like 'a fish out of water.' Answering the call of academe, he joined the teaching faculty at Hamilton's McMaster University in the late 1960s to pursue his real scholarly passions. He was a classicist and a royalist deeply committed to exploring the philosophic roots of British and Canadian conservatism. While studying History at the University of Toronto, Daly had fallen under the influence of J.B. Conacher, D. J. McDougall, M.R. Powicke, and W.W. Piepenburg, scholars who introduced him to Sir Robert Filmer (1588-1653), a prime defender of English royalism and the "fatherly power " of the "divine right of kings." In his most substantial published work, Sir Robert Filmer and English Political Thought, he paid tribute to his mentors: "If the tree amounted to something, it was they who bent the twig." 11

Most of Daly's academic concerns focused on English history, political philosophy, 
and the medieval world. What seemed esoteric to many fellow scholars and colleagues, absolutely fascinated the young Daly. The majesty and moral standards represented by English royalism fired his imagination. Like Filmer, he became a defender of "the Natural Power of Kings" against the "Unnatural Liberty of the People." He came to harbour dark suspicions about the European Enlightenment, and particularly the libertarian views of John Locke. Filmer's critics, including Locke, he believed had missed the originality in his political thought and done both him and all royalists a great disservice. Modern liberal thought, according to Daly, was an abomination, an artificial construct that amounted to little more than "a scheme" whereby "selfseeking individuals might find a maximum of satisfaction." ${ }^{12}$

Traditional conservatism had great appeal for Daly. It was rooted in English political ideas and a staunch loyalty to the monarchy, a brand of Toryism far removed from today's North American marketplace conservatism. His educational philosophy derived from similar sources. Upon closer scrutiny, he was what Campbell A. Ross would describe as a quintessential Canadian educational conservative. ${ }^{13}$ Like Hilda Neatby, the respected historian and author of So Little for the Mind (1953), Daly based his educational conservatism upon a desire to conserve and uphold the ideal of producing a truly "educated person." In their view, the purpose of education was, first and foremost, to both preserve and to transmit the history and culture bequeathed by Western Europe and England in particular. ${ }^{14}$

Before he surfaced as a leading Hall-Dennis critic, Daly was already attuned to what he described as the "contemporary crisis of our semi-liberal social order." ${ }^{15} \mathrm{He}$ sympathized with Canada's leading conservative thinkers, George Grant and W.L. Morton, but was troubled by their "pessimism" in the face of technological progress and their rejection of "the teleology of traditional Christianity." It concerned him that, while Morton recognized the organic nature of conservatism, he showed a disregard for the Christian foundations of his own political philosophy. Daly's personal search for a philosophic basis for Canadian conservatism led him to question "the Stoic pessimism of a Grant" and "the defiant scepticism of Morton." Our whole Western world was, in Daly's words, "awash with liberal and radical notions." Liberalism was showing its ugly face in the form of "value-free social scientists, the liberal-intellectual communications complex," and "the whole liberation neurosis." What Michael Oakeshott termed "prudential conservatism," the so-called conservatism of method, Daly came to believe must be combined with "an essential conservatism" or a conservatism of content resting upon a heritage of accepted beliefs. ${ }^{16}$

\section{The Dire Threat — “Doing Your Own Thing” Progressivism}

The initial euphoria that greeted the Hall-Dennis Report confirmed the worst fears of traditionalist educators in Ontario and far beyond. When the Report was released on June 12, 1968, the Toronto media were effusive in their praise for the three-year study with its 258 sweeping recommendations. It was "a revolutionary blueprint for education," The Toronto Daily Star proclaimed, and nothing short of "a radical program to liberate our school system." ${ }^{17}$ Even the normally dour Toronto Globe and 
Mail jumped on the bandwagon. With a big splash, The Globe's news team of Barrie Zwicker and Douglas Sagi welcomed the Report as one that recommended "Ontario's educational system be turned upside down and all the old ways of doing things be shaken from it." NDP Opposition Critic Walter Pitman, a former Peterborough history teacher, was generously quoted in the paper. "This is a tremendous document," Pitman declared. "It will change the face of education. Instead of being subject-orientated, it will be experience-oriented. It will produce a more sensitive compassionate person who sees learning as a delight rather than a job." ${ }^{18}$ Education Minister Bill Davis's mere presence at the official announcement was interpreted as an endorsement, even though he cautioned that it was only "a step in the right direction for planning." 19

The initial editorials were equally rapturous and reflected the irreverent spirit of the times. In its lead editorial, The Globe and Mailheralded the Hall-Dennis Report as truly revolutionary in the sense that, unlike other commission or inquiry reports, it would not be "retired to gather dust." Its ringing endorsement of the report was total and unqualified: The school system it envisions would abolish all the multiplicity of rigidities that now dominate the child, and set him free to search, with assistance, for the truth....

What the report does is to set a goal-creative, conscienceful (sic), human - away out ahead of the solemn strivers in the present educational prisons. It may frighten and infuriate, but by degrees, it will also force, by its sheer rightness, the changes that we all know must be made. ${ }^{20}$

Not to be outdone, The Toronto Daily Star appropriated "the language of the hippies" and noted that the Report "advises us to let every schoolchild 'do his own thing."” Conscious of how it sounded, the editorialists hastened to add that the "carefully reasoned recommendations of this excellent report" would never "stoop to such 'pop' language." ${ }^{21}$ But it was too late for such qualifiers. Most of the popular commentaries latched onto the line that the Report was an open invitation for students to "do their own thing" in Ontario's public schools.

The Report was greeted with what Daly aptly described as a chorus of "hosannas and hallelujahs." The Globe and Mail's influential and widely-read columnist, Richard J. Needham, quickly emerged as one of the Report's champions. He was, in the mid-to- late1960s, a popular but quixotic Toronto cultural figure, a balding, pipesmoking and a 'pied piper' for the rising youth culture. Viewed by most parents as an aged "hippie," he paid close attention to, and gave voice to, the young and restless. Needham's daily newspaper ramblings were wildly popular with school teachers and even read by more studious teens. ${ }^{22}$ His freely dispensed views carried considerable weight and so did his pronouncements on the Report. "It's a good report," he told his readers, because it reflected "what he had observed visiting hundreds of public schools over the previous three years." In Needham's familiar overblown rhetoric, it promised an end to "fear, threats, humiliations, beatings..." He went even further. The "Ontario Establishment," he wrote, "lives by fear, threats, humiliations, 
beatings; being anti-people. It doesn't know any other way to run things..." He then offered this memorable prediction:

[T] he schools will keep right on being at worst operated like grim penitentiaries and at best like cloistered monasteries - cut off from the real world of life, strife, adventure, change, triumph, disaster, action, beauty, glory, and poetry. Stop thinking about the Taj Mahal and get your nose into that algebra book! Don't you want a good job in the glue factory? ${ }^{23}$

Inciting rabid debate and stirring a reaction was his stock-and-trade and the HallDennis Report provided him with plenty of fodder.

Socially aware Ontario teens and 'hip' high school teachers simply ate up Needham's regular comments, especially on the subject "doing your own thing" over the objections of stuffy, old-fashioned parents. ${ }^{24}$ One of those receptive teens was Fred Freeman, a politically-active Grade 11 student at Toronto's Bathurst Heights Collegiate. He wholeheartedly agreed with Needham. There was "something wrong with the way high schools are run," he told The Toronto Daily Star. "Who else can decide what a student is to learn except the student himself,?" he asked, before complaining that being forced to study Latin from Grade 10 onward squelched his enjoyment of learning. ${ }^{25}$ Such viewpoints only echoed those of Needham and fixed, in the public mind, the distinct but rather misleading impression that the Report was a colourful recipe book for an "anything goes" brand of education.

\section{Constructing a Consensus for Progressivism}

The Report did not spring out of nowhere. It was actually an outgrowth of the progressive educational philosophy being espoused by Deputy Minister McCarthy. What had begun in 1965 as a modestly conceived elementary curriculum review had gradually morphed into a full-blown committee of inquiry into the aims of education with an ever-expanding mandate. ${ }^{26}$ The Committee, as Eric W. Ricker demonstrated, was a classic example of a bureaucratically-driven consensus-building exercise. It was structured in a fashion recommended by McCarthy and the Department; its agendas and working papers were drafted by Department staff; almost all of the initial expert testimony was provided by the 'educrats;' and, finally, a number of its key members were "insiders' - close associates, or former teachers and professors, of members of the Department's curriculum branch. Although the Committee of 22 appointed members was described by Lloyd Dennis as a group of "all sorts" chosen from a "grab bag," it was, in Ricker's words, "clearly biased before its work even commenced.” 27

In the three-year-long study, McCarthy and his officials skilfully steered the Committee in the direction of "progressivism." While the Committee had its share of traditionalists, as well as a number of Catholic members, both French and English, the progressives gained the upper hand in its internal workings. The predominantly child-centred philosophy conveyed in the briefs was reinforced by the" professionals" relatively unencumbered by the usual teacher federation pressures and constraints. 
The addition of Charles E. Phillips, the reputed dean of Canadian educational history, to the Committee strengthened the hand of progressives. Most significantly, the Ontario Secondary School Teachers' Federation (OSSTF), which favoured a reformed traditionalist approach, was effectively marginalized on the Committee. The OSSTF's one lone representative was, in fact, no longer a high school teacher by the time the Committee got down to serious work. ${ }^{28}$ Under such favourable conditions, the progressive educators were able to seize the initiative in not only planning the Committee's work, but also in drafting its recommendations.

The senior figure behind the venture, Justice Emmett Hall, bowed out with the Report's appearance. From the time of its release until June 1969, Co-Chair Lloyd Dennis had embarked on a "road show" to promote the Hall-Dennis Report and its recommendations. His zealous, super-charged message capitalized upon the initial favourable reviews and buoyed the spirits of educational progressives across Ontario and in every other province and territory. Hired by the Department under contract, he delivered a folksy, entertaining talk and gave " 285 speeches in 180 working days" over nine months promoting the Report. ${ }^{29}$ With this active promotion, the glossy Report became a bestseller with 60,000 copies either sold or in print. It was deemed required reading in all of Ontario's teachers' colleges and education faculties. One year after its release, The Toronto Daily Star reported that Committee members had given over 600 speeches reaching live audiences approaching 250,000 persons; in addition, some 100 conferences had been held and special committee were at work in almost every Ontario school system. ${ }^{30}$

\section{The Gathering Storm of Opposition}

The first salvos against the Report rang out from the halls of higher learning. Within a week of the Report's release, three senior university academics had written scathing Letters to the Editor, each published in The Globe and Mail. The Chairman of York University's Physics Department, R.W. Nicholls, expressed alarm over "the apparent naiveté" of many of the recommendations, questioned "removing the structure from the school system," warned about school years being "squandered on trivialities and fads," and objected to removing "all signposts of competitive success (grades, etc)." ${ }^{31}$ In a thoughtful, considered response, economics professor Ralph Blackmore of Waterloo Lutheran University expressed similar concerns. He wondered if the Report would lead to "watering down of standards" for students and whether it might "turn them out naked and unprepared into a tough and competitive world." ${ }^{2}$ Professor D.J. Dooley of Toronto's St. Michael's College registered a serious concern that "the new system" would promote "a narrowness of interest" focused on "current events and contemporary issues." Instead of promoting intellectual curiosity, he forecast that it would equip students, "at great expense, with very effective sets of intellectual blinkers." 33

One of the most influential early critics was J.H.R. Morgan, the Secondary School Liaison Officer at the University of Toronto's College of Education. Speaking at a "Teach-In" on January 11, 1969, he weighed in on the Hall-Dennis Report in a most effective fashion. After crediting the Report for spicing-up "the standard and 
somewhat bland educational diet," Morgan proceeded to analyze the Report's underlying philosophy and implications. He expressed concern over "band-wagon thinking" and set out to help partisans see "both sides of the coin." While Morgan acknowledged that the Hall-Dennis prescription had remarkable appeal, he cautioned against the dangers "band-wagon thinking." He noted that the adoption of a new "set of shibboleths" by the otherwise "unimaginative teacher" would "not, of itself, bring about any new heaven and new earth." Teachers, according to Morgan, would continue to play an instrumental role if "experiential learning" was to "lead the child anywhere," particularly in the higher grades. He directly challenged the Report's basic assumption that adolescents, in particular, were mature enough to pursue "learning for its own sake." The Report was, in his words, "a little starry-eyed" and might well lead "a whole generation down a slippery slope." 34

Public opposition was muffled at first, but gradually began to be voiced, first by academics, then by secondary school teachers. University of Toronto English professor John M. Robson threw a well-timed dart on September 2, 1969, marking the first day of school with a column paying homage to Hilda Neatby's So Little for the Mind and predicting that "Johnny" would now be doing more "living than learning" in Ontario's schools. ${ }^{35}$ At Althouse College, University of Western Ontario, Geoffrey Milburn and Gary Meadows raised objections to the Report's assault on history as a subject discipline and warned that educational equalitarianism had often been associated with "intellectual flabbiness." Meadows went so far as to predict that "those tardy souls who need a little pushing to sweat for their knowledge" would provide "a classic monkey wrench for Ontario education a la Hall-Dennis." ${ }^{36}$ High school history teacher Norman Sheffe was more muted in his criticism, but reported that the upheaval caused by the Report left his fellow teachers feeling like "Hansel and Gretel after the birds had eaten up the trail of bread crumbs." ${ }^{37}$

A massive survey conducted in the spring and summer of 1969 by the Ontario Teachers' Federation polled 6,127 teachers and purported to demonstrate that most teachers supported the general philosophy espoused in the Report. ${ }^{38}$ Yet many Ontario teachers felt threatened by the call for a fundamental change in methods and even potential allies, such as Toronto's George Martell of This Magazine is About Schools, found fault with the supposedly "liberalizing" education manifesto. To Martell and more radical progressives, the emphasis on "individualized" learning was seen as corporatist idea threatening to undermine the "sense of community" in public schools. ${ }^{39}$

The periodic murmurs of misgiving began to turn into signs of protest, in spite of Lloyd Dennis's strenuous missionary efforts. On his travels Dennis found that the warm reception accorded the Report at the initial Toronto news conference did not guarantee a positive reception in the wider world of public education. When Dennis spoke at McMaster University, he entered a virtual lion's den. Professor Daly glared at Dennis and the normally impartial meeting chairman, John Trueman, could not resist making his personal views known. ${ }^{40}$ In some places, Dennis was lustily booed. School trustees, departmental officials and even Education Minister Davis became irritated by his unrelenting attack upon the existing system as rigid and stultifying for students. After nine months, Dennis's contract was not extended, and he was 
told that there was no job for him in the Department. At age 44, he found refuge as a Director of Education in Leeds Grenville County Board, a frontier regional board with 50 scattered schools and so few student support services that 1 psychologist served some 17,000 students. ${ }^{41}$

One of the largest conferences held on the Hall-Dennis Report, "Re-Thinking Education," held on April 17-19, 1969, proved to be a major letdown for Dennis and his allies. Sponsored by the Ontario Institute for Studies in Education (OISE) and attended by between 300 and 350 people of all ages, from students to education's elder statesmen, it exposed the division of opinion over the Report and, by all accounts, left many Ontario educators bewildered and confused. ${ }^{42}$ Education Minister Davis opened the Conference by distancing himself and the Department from the Report. It was, he stated several times, "not a statement of government policy," but rather a set of recommendations requiring continuing review and discussion. On matters of education policy, he quipped, finding "a consensus among academics" was "simply not to be expected." If such a consensus were to materialize, around matters other than the need for more funding, Davis commented wryly, "I'll feel there's something wrong in education!" In his speech and throughout the conference, the Minister and his officials were at pains to assure everyone that, aside from one or two regrettable "official urgings" during 1968-69, Ontario educational authorities favoured a period of gradual, incremental change, building upon individual innovations and continuing dialogue, all aimed at producing "genuine and lasting improvements" in teaching and learning. ${ }^{43}$

The official OISE Conference Report, written by James M. Paton of Toronto's College of Education, confirmed that the initial wave of support had dissolved into choppy waters. While paying tribute to Dennis's infectious enthusiasm, he left no doubt that his "dramatization of school problems and his Rousseauesque descriptions of the nature and potential of children troubled a great many professional teachers, especially those experienced working with adolescents." The critics and the doubters attending the Conference, he reported, "outnumbered the wholehearted supporters of the Hall-Dennis Report." After revealing his personal bias which he termed "neorealist," Paton proceeded to catalogue the prime sources of confusion and contradiction inherent in the report. Counted among them were "misunderstandings" over such fundamentals as individual wants and social needs, learning theory, passing and failing students, and the publishing of class set or school-wide measures of progress. The conclusion he reached was startling, especially for Hall-Dennis supporters: "No longer will it be regarded as Holy Writ, the pure Milk of the Word....” The Report, Paton added, may well have "performed a useful function in stimulating the desire to change by exposing specific weaknesses; but it also raised more questions than it provided answers." 44

\section{James Daly's Critique of the Hall-Dennis Concoction}

The Hall-Dennis Report was Dr. James Daly's worst nightmare and he did not mince any words. His little booklet appeared in the fall of 1969 and described the whole 
concoction as "a bucket of molasses, sticky sentiment couched in wretched prose." The language was characteristically florid, yet his concerns ran much deeper. "The besetting fallacies," Daly wrote, "have dangerous consequences far beyond the schools. The general public would be the eventual victims of what one must regretfully call an assault on civilization as we know it." The Report was ill-considered and threatening because of "the real nature of its prescriptions, which would imply a revolution in the relation between children and adults, a revolution in the school, the family, and ultimately in the society." Daly predicted that, even though its prescriptions would not likely be "widely followed," the Report may still inflict "terrible damage" on the schools. "The illusions to which it gives such prestige are already at work; it will help them in their evil careers." 45

Daly's Education or Molasses? greatly expanded upon the academic critique and it established the McMaster historian as the Report's most outspoken critic. The Report's almost obsessive focus on education for personal fulfilment provoked his barely concealed outrage. For a scholar steeped in classical education, the Report bordered on blasphemy because it challenged the Western Canon, considered by Daly to represent the wisdom of the ages. In chapter 2, 'The Ghost of John Dewey,' he took dead aim at the "central assertions" of the document and imparted his own interpretation:

Poor performance by children is the fault of the system or the teacher, not the child; learning is a pleasant experience - unpleasantness makes learning more difficult; punishment is seldom or never justified, and corporal punishment never; students should be given a maximum of choice in what they learn; the purpose of education is not to introduce the child to the customs and tradition of the adult world, but to those of a world which will be inconceivably different - that is, the purpose of education is to prepare the young for a world of Change. ${ }^{46}$

In Daly's view, the essentials of education were under siege. In its spirit and tone, the Report represented a virtual declaration of war against traditionalism. It may have simply reflected the prevailing liberal reformist winds of the $1960 \mathrm{~s},{ }^{47}$ but to him it amounted to a call to arms.

The Report's most ferocious critic was appalled at its soft, wholly-headed view of the acquisition of knowledge and its narrowing of the whole concept of learning. In chapter 3, he argued that the Report attempted to separate two inseparable aspects of learning - content and process. It was a grave mistake to assert that "how to learn and think" mattered more than "what to know and remember." He took exception to the standard progressive line that "we teach the child, not the subject." "Can the child learn without learning something?," he asked rhetorically. His answer: "learning means learning something." Turning another Hall-Dennis mantra on its head, Daly offered this dictum: "Education is a process not a thing, but it is a process by which things are learned." 48

Daly also rejected the basic assumption of Living and Learning that the child is a "natural and self-propelled learner." "The innocent child motif," Daly stated, was 
"part of another grave failing." He could accept that the younger child showed an inclination to be an instinctive learner who, with encouragement, would educate himself. Yet "children" of 16 years of age, Daly pointed out, were at a different stage in human development:

The insistence in the Report on eliminating real divisions between kindergarten and grade twelve makes all too easy the blurring of distinctions, so that the touching characteristics of six-year-olds excuse the very different behaviour of those much older. One can applaud the almost maternal solicitude for very young children; there are teenagers who are in need of a different kind of sympathy! ${ }^{49}$

What might work in early childhood education was simply not appropriate for educating adolescents who, left to their own devices, might choose to take the easy road. That was also a sentiment strongly expressed by J.H. R. Morgan and a growing body of secondary school teachers. ${ }^{50}$

\section{The Lonely Crusade and Its Impact}

Daly's pamphlet knocked the wind out of the sails of the flagging Hall-Dennis reform movement. His first 500 copies, printed by Cromlech Press in Ancaster, Ontario, sold out in one week. In an influential October 1969 commentary, Toronto Telegram columnists Douglas Fisher and Harry Crowe welcomed Daly's potent little jeremiad with open arms. ${ }^{51}$ After reading the document in mid-1968, they had become, in their own words, "sworn enemies of the report." Their terse assessment: "We think it windy and dangerous." They found common cause with Dr. Daly and spoke approvingly of his little "pocketbook." Their response echoed Daly's criticism of the Report and of its "roving evangelist," Lloyd Dennis. "He manhandles Mr. Dennis," they wrote, and demonstrates that his foolishness wouldn't be so dangerous except that (unfortunately) it seems to have the sanction of the top department bureaucrats."

Fisher and Crowe heartily agreed with Daly on his assessment of John Dewey's continuing influence. To reaffirm their point, they highlighted this key passage: "some people may regard...the report as the latest thing in educational thought; it is in fact a latter day reflection of the 50-year old theories of John Dewey in a crude and outdated form." They too seriously questioned the assumption that children in kindergarten or Grade 3 or even Grade 9 were ready for "democracy" and claimed that "anarchy stems from pushing this kind of democratic participation in the schools." In a final flourish, they urged both William Davis and Jack McCarthy to not only read it, but to absorb its lessons. ${ }^{52}$

Daly's stinging critique, summarized in the Fisher and Crowe column, was taken up by teachers who took exception to Living and Learning. Many educators saw the Report, in the words of the Telegram columnists, as "a blanket slander of Ontario teachers." Abandoning structured approaches to learning, giving students a broad menu of course choices, and phasing-out grades and examinations were not popular, 
especially with seasoned secondary school teachers. Most felt threatened by the rapidity of the changes and saw their ability to control classes gradually slipping away. Educational critics such as Brian Crittenden of Toronto's Ontario Institute for Studies in Education, poked holes in the Report's exclusive focus on the "individual child" and its weakness in applying the latest educational research in pedagogy, inquiry methods, and integrated learning. ${ }^{53}$

The charge that the Hall-Dennis Report sought to disassemble the prescribed curriculum provoked genuine outrage. Seeing the Report's evidence drawn mostly from the early grades, academically-inclined teachers instinctively agreed with Daly that the proposed Hall-Dennis curriculum as a "melange of mush" organized around little more than "general areas of learning." With the proposed abandonment of prescribed curricula, teachers would be left on their own to design new curricula without any training in the field. Academics and classroom teachers alike claimed that the Report utterly failed to make adequate provision for certain "core subjects," such as English, Mathematics, and Science, which were essential for an effective, balanced curriculum. ${ }^{54}$ Ontario's History and Social Studies teachers complained about the proposed curriculum's presentist bias and seeming acceptance of the assumption that "the present and the future are all that matters." After viewing the resulting Ontario History Guidelines, John Ricker, Chairman of History at Toronto's Faculty of Education, confirmed their worst fears, declaring the Hall-Dennis-inspired changes "an invitation for teachers to do their own thing." 55

Daly's little crusade generated some public turbulence, encouraged dissenting teachers, and presented a notable bump on the pot-holed road to progressive reform. The Ontario Teachers' Federation planned a province-wide Professional Development Day for October 8, 1969 so elementary and high school teachers could meet to discuss Living and Learning. It fizzled when most of Ontario's school boards scuttled the "Hall-Dennis Day," against the wishes of the OTF and Department. While most of the 6,100 teachers surveyed by OTF favoured the Hall-Dennis Report's "studentcentred" philosophy, opinions were more evenly divided on specific recommendations. ${ }^{56}$ Much of the critical fire was aimed at two recommendations lambasted by Daly: the establishment of an ungraded, exam-less system of "continuous progress" without failure and the proposed new curriculum organized around "general areas of learning." Shortly after the publication of Education or Molasses?, even The Globe and Mail began to change its editorial tune. That change was captured well in a Commentary, published on the aborted "Hall-Dennis Day" and aptly entitled "Learning to live with Hall-Dennis." 57

\section{Slowing the Relentless March of "Progressive" Reform}

In spite of the public outcry, Daly's crusade failed to halt the steady advance of Hall-Dennis curriculum reform in Ontario. The Report not only reinforced but gave fresh impetus to experiments already underway in the Ontario school system. Beginning with the abolition of the Grade 13 departmental examination system in 1967 , McCarthy and his officials were actively engaged in transforming the schools. 
The end of departmental examinations coincided with other major changes aimed at dissolving the 1962 Reorganized High School Programme, known as the "Robarts Plan." In place of the three branches of study, academic, technical and commercial, and grade promotion, officials were moving forward with a new "credit system" based upon the accumulation of individual course credits. ${ }^{58}$

Without official fanfare, a few secondary schools were already experimenting with the new system while the intense Hall-Dennis Debate raged around them. Six secondary schools had introduced the new "credit system" in 1968-69: Parkside High School in Dundas, Newtonbrook Secondary School in North York, OakvilleTrafalgar High School in Oakville, Fisher Park Secondary School in Ottawa, Sir John A. Macdonald Collegiate in Scarborough; and Malvern Collegiate Institute in Toronto. A unique trimester system, which enabled students to choose different subjects each term, and to switch levels in mid-year, had been adopted in 1967-68 at Thornlea Secondary School in Thornhill. ${ }^{59}$ To Daly and his determined allies, the relentless advance of 'creeping progressivism' appeared unstoppable.

While Daly was writing Education or Molasess?, the Ontario secondary school system was in a state of upheaval. Eight months after the release of Living and Learning, in March 1969, Minister of Education Davis had announced a brand new system of organization. At a meeting of the Ontario Secondary School Headmasters' Council, he unveiled a new individualized program modelled after the Hall-Dennis formula and bringing an official end to the more structured, academically-driven Robarts Plan. ${ }^{60}$ New departmental guidelines for 1969-70 carried it one step further, giving secondary schools a choice between the old Reorganized Programme and a "credit system" with 27 course credits needed for a Grade 12 diploma. That Credit System, first proposed in Circular H.S.1 for 1969-70 and completely adopted in 1972-73, was significantly advanced by means of the Hall-Dennis Report. ${ }^{61}$ All of these changes went forward amid the public controversy generated by the Report and Daly's stinging response.

Once the Great Debate over Hall-Dennis died down, Daly receded from public view and poured his full energies into academic and spiritual matters. He and his wife Janet (Ward) Daly were busy raising five children on an Assistant Professor's salary at McMaster for most of the 1970s. In the aftermath of the October 1970 FLQ Crisis, Daly achieved some notoriety by speaking out in favour of the imposition of the War Measures Act. Writing in Canadian Forum in April-May 1971, he roundly condemned the "now-fashionable intellectual radicalism" that disparaged political institutions, undermined public authority, and weakened the social order. Fresh from his Hall-Dennis clashes, Daly saw the "bleeding heart liberal" response to the October Crisis as confirmation that the "Canadian intellectual-communications complex" was relatively small, but "ingrown, almost completely liberal or super-liberal (i.e. radical)." 62

He retained a keen interest in the travails of Ontario education. As a university professor, he set extraordinarily high standards and exhibited a notable pedantic streak. His 1974 book review of W.G. Fleming's Education: Ontario's Preoccupation revealed that he was beginning to come to terms with his own dramatic foray into 
Ontario educational politics. While crediting Fleming for his surprisingly balanced approach, he recognized that, like the author, the 1960s had been "a time of defeat" for defenders of "essentialist" education. He quibbled about Fleming's harsh treatment of fellow traditionalists like Hilda Neatby and former Ontario Education Minister W.J. Dunlop. Nonetheless, Daly recommended the book as a reliable guide to the "crisis-ridden education system." ${ }^{63}$

\section{The Final Crusade - for Catholic Orthodoxy}

Dr. James Daly was always a devout Roman Catholic but when the Hall-Dennis Debate passed, he became more and more absorbed with theological matters. Daly met and enjoyed the company of a remarkable fellow historian, John Muggeridge, son of the English intellectual giant Malcolm Muggeridge. Like Professor Daly, John held a Graduate degree from the University of Toronto and taught the academic subject at Ridley College, Earl Haig Collegiate, and eventually at Niagara College in Welland, Ontario. ${ }^{64}$ After marrying Anne Roche, Muggeridge converted to Catholicism and eventually became close friends with James and Janet Daly. Both couples were firm believers in the "Right to Life" movement and became gravely concerned over liberalizing trends within the Holy Catholic Church.

In the early 1970s, James and Janet Daly joined with John and Anne Muggeridge and a St. Joseph's nun, Sister Mary Alexander, in forming a Catholic society to uphold Catholic religious piety and orthodoxy. Their religious group was called the Saint Athanasius Society, which took its name from the fourth century saint who defended Catholic orthodoxy against Arianism. The Daly's and the Muggeridge's admired Saint Athanasius, the Father of Orthodoxy, for defending Christ's divinity

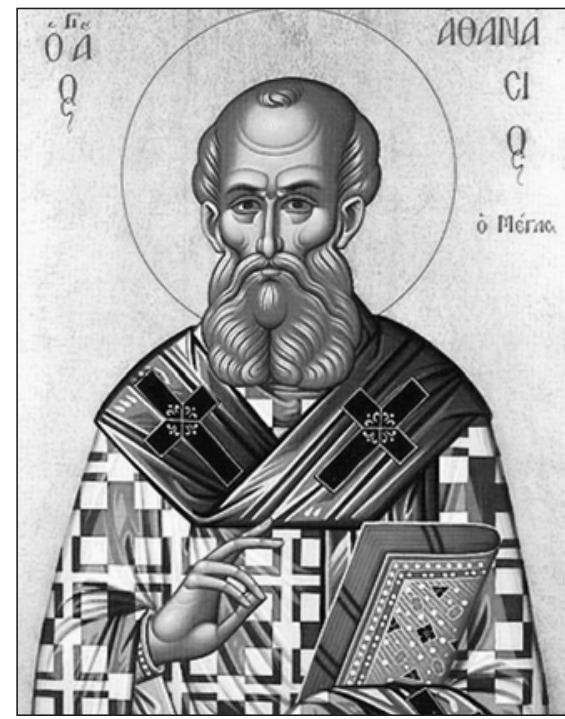

Figure 4: The Final Crusade — for Saint Athanasius. against the heresy of Arianism, which claimed that God was "uncreated" and therefore, eternal, but Christ, the Son of God, was "created" and thus not eternal. Following Saint Athanasius's Christian example, society members had a profound devotion to the Blessed Virgin Mary and an abhorrence of abortion which they saw as taking the life of an unborn child. ${ }^{65}$

The Saint Athanasius Society was fired by religious indignation aroused by the Second Vatican Council of the Catholic Church. Within the group, James Daly provided the organizational drive and John's spouse, Anne Roche, the theological militancy. Anne was particularly concerned about the threat to Christian family life. Alarmed by the 
laxity of the Catholic hierarchy, Anne wrote a provocative magazine article entitled "What do you do when your church leaves you?" In 1975, she followed up with the first of her two books, The Gates of Hell, a dire warning about the drift and degeneracy within the Catholic Church. ${ }^{66}$ Like Anne, James and Janet Daly were completely preoccupied with what they termed "the scourge of abortion" in Canada. With the premature death of James Daly from leukemia in November 1983, the Society withered and, according to Catholic Insight magazine, "suffered a blow from which it never recovered." ${ }^{67}$

\section{The Legacy of James Daly and His Little Pamphlet}

Dr. James Daly never did get any respect from either the Ontario educational establishment or the polite Toronto professional circles. While many secretly admired his courage and delighted in his prose, he proved easy to dismiss. The educational reform tide of the 1960s was not kind to philosophical conservatives like Daly. He was a rather rotund, pedantic English historian, a committed classicist, and a staunch royalist, as well as a Hamiltonian from McMaster, that formerly Baptist university down the QEW en route to Niagara Falls. Like many intensely focused academics, he could be prickly and he possessed, in John Trueman's words, "a genius for repelling others." ${ }^{68}$ That made him easy to caricature as an eccentric contrarian if not an academic 'wing-nut.' Whereas Committee co-chair Lloyd Dennis proved to be a bouncy, pugnacious promoter of the Report, ${ }^{69}$ Daly tended to lecture, in ponderous fashion, preferring to let the written text speak for itself. In the raging public debate over the Hall-Dennis Report, Dennis scored most of the headlines, the unabashedly conservative McMaster history professor found vindication after his passing.

While Daly's little book echoed the essential message of Hilda Neatby's So Little for the Mind (1953), it never attracted the same popular acclaim. Many Canadian educators from regular classroom teachers to academics sympathized with Daly, but few rallied to his defence in the ensuing public debate. Gradually throughout the 1970s, while Daly was totally immersed in teaching and preparing his $\mathrm{PhD}$ thesis on Sir Robert Filmer for publication, it became increasingly apparent that Living and Learning had unleashed a whole series of unplanned, uncoordinated changes in Ontario education. ${ }^{70}$ After some initial flirtations with Hall-Dennis reform, most of the other provinces absorbed the lessons of the bitter divisions aroused by forcing the progressive educational agenda. Education observers in Maritime Canada were totally unmoved by the excitement generated by Living and Learning. In Nova Scotia, Deputy Minister of Education Harold M. Nason remained extremely cautious, even after being prodded by his Ontario counterpart, Jack McCarthy. "The history of educational development," he said at the 1969 Canadian Education Association Conference," is a history of compromises and adjustments" where "change takes time." ${ }^{71}$ In May 1971, Maritime educator Russell Hunt put it more bluntly in a review of Satu Repo's This Book is About Schools. "The crest of the liberal education reform wave in Ontario was marked by the establishment of OISE... and by the publication of the splashily-produced Hall-Dennis report," he wrote. That very report, 
he added, provided a clear sign that "liberal reform of public education was to prove a failure." Mandating uniformity, even under the guise of "student-centred learning," simply would not work. "A large, centralized, uniform system of public education, it is becoming increasingly clear cannot be responsive to the different demands and needs of individual parents and students." 72

Daly's personal crusade failed to roll back Hall-Dennis-inspired 'romantic progressive' reform but his message eventually sunk in, even within the bowels of the Ontario Department of Education. Back in 1969, a young, untenured McMaster English history professor stepped forward where others feared to tread. Well-known history textbook author John Trueman describes it now as "the beginning of the slide" in Ontario education. It fell to Daly to carry the torch in opposition to the assault on knowledge-based curriculum. He entered the fray against Jack McCarthy, Lloyd Dennis, and the purveyors of what he termed "Edutopia." By January 1983, the bloom was off the Hall-Dennis rose and The Globe and Mail published a news feature by Judy Steed entitled "Crisis in the Schools." West Toronto history teacher John Sheppard told Steed that teachers held the Hall-Dennis Report responsible for "destroying education in Ontario." With Daly in the final stages of his life, he must have smiled at the story proclaiming the Hall-Dennis era finally over. "Now, it's the eighties," Steed stated, "and it's back to the basics with more structure." ${ }^{3}$

The Hall-Dennis experiment continued to haunt Ontario education long after Daly's passing. Cycles of educational reform throughout the 1980s and 1990s were often benchmarked against, or launched to bury, the supposed Hall-Dennis model of child-centred "progressivism." In subsequent public debates, the Hall-Dennis legacy was hotly debated, but the name James Daly rarely invoked. Yet, some 25 years after he passed away, his core message was being voiced by a new generation of essentialist educators and concerned parents beating the drum for higher standards, testing and accountability. ${ }^{74}$ One such education critic, Tami Paikin Nolan, writing in The Hamilton Spectator in April 1993, did appropriate Daly's "boldly prescient" message and his colourful language. With Bob Rae's NDP government promoting a Common Curriculum for Grades 1 to 9, she saw the move to "destream Grade 9" as sad reminder of Daly's vain attempt to vanquish the "pseudo-psychedelic propaganda" of the Hall-Dennis Report. ${ }^{75}$

\section{Notes}

An earlier version of this paper was presented at the Canadian History of Education Conference, held October 23, 2010 in Toronto and sponsored by York University's Faculty of Education. The author wishes to acknowledge the assistance of John H. Trueman, Beverly A. Bayzat, Paul Axelrod, and Robert N. Berard in the preparation of this article.

1 Personal Interview, John H. Trueman, 16 September 2010, Hamilton, Ontario.

2 James Daly, Education or Molasses? A Critical Look at the Hall-Dennis Report (Ancaster, ON: Cromlech Press, McMaster University, 1969). The pamphlet-sized book was a direct response to Living and Learning: The Report of the Provincial Committee on Aims 
and Objectives of Education in the Schools of Ontario (Toronto: Ontario Department of Education, June 1968)

3 See Living and Learning, 9 and 21; and John Dewey, Democracy and Education (New York: Free Press, 1966), 6, 8, 20, and 114.

4 See Living and Learning, p. 121; and John Dewey, My Pedagogic Creed (1897), 9, accessed at http://en.wikisource.org/wiki/My_Pedagogic_Creed (17/03/11)

5 See R. D. Gidney, From Hope to Harris: The Shaping of Ontario's Schools (Toronto: University of Toronto Press, 1999), 66, and 69-86. On the illusory appeal of the Report, see Brian Crittenden, "Slogans - handle with care," in Crittenden, ed., Means \& Ends in Education: Comments on Living and Learning (Toronto: Ontario Institute for Studies in Education, 1969), 25-42.

6 Eric W. Ricker, "Teachers, Trustees and Policy: The Politics of Education in Ontario, 1945-1975," Unpublished PhD Thesis, University of Toronto, 1981, 487-488.

7 Daly, Education or Molassses?, esp. 1-2.

8 One of the few exceptions is Frederick Vaughan, the Canadian legal historian with a special interest in Justice Emmett Hall and his legacy. His biographic study of Hall recognizes Daly's pivotal role in challenging the assumptions of progressive education. See Vaughan, Aggressive in Pursuit: The Life of Justice Emmett Hall (Toronto: University of Toronto Press, 2004), 158-159.

9 Gidney, From Hope to Harris, 75-77 and 311.

10 Ken Osborne, Education: A Guide to the Canadian School Debate - Or, Who Wants What and Why? (Toronto: Penguin Books, 1999), 14-15.

11 James Daly, Sir Robert Filmer and English Political Thought (Toronto: University of Toronto Press, 1979), Dedication.

12 James Daly, "Cosmic Harmony and Political Thinking in Early Stuart England," Transactions of the American Philosophical Society, Vol. 69, Part 7 (October 1979), pp. 37-38.

13 Campbell A. Ross, "'Only in Canada? Pity: The Sad Fate of Educational Conservatism in Canada," Historical Studies in Education, Vol. 8, No. 2 (1996), 226- 227.

14 Hilda Neatby, So Little for the Mind (Toronto; Clarke Irwin, 1953), Preface. For a fuller analysis, see Campbell A Ross, "The Neatby Debate and Conservative Thought in Canada," PhD Thesis, University of Alberta, 1989). See also H.G. Rickover, Education and Freedom (New York: E.P. Dutton, 1959) for another variation.

15 J.W. Daly, "Toward a Philosophic Basis for Canadian Conservatism," Journal of Canadian Studies, Vol. V, No. 4 (November 1970), 50.

16 Daly, Toward a Philosophic Basis for Canadian Conservatism," 50-57.

17 The Toronto Daily Star, 13 June 1968, 1 and Editorial, 6.

18 The Globe and Mail, 13 June 1968, 1

19 See "Davis Hails Hall's Blueprint for Change," The Toronto Daily Star, 13 June 1968, 1

20 "No Dust-Gatherer, this," Editorial, The Globe and Mail, 13 June 1968, 6. See also The Toronto Telegram, June 12 and June 13, 1968.

21 "A Radical Program to Liberate our School System, "Editorial," The Toronto Daily Star, 13 June 1968, 6. For a laudatory review of Living and Learning, see Douglas Myers, "The Hall Dennis Report," Canadian Forum, (September 1968), 136-140.

22 For insights into Richard J. Needham, see his popular collections of writings, particularly, The Hypodermic Needham (Toronto: Simon and Schuster, 1975); and You and all the rest: The Wit and Wisdom of Richard J. Needham (Toronto: M. Sutkiewicz Publishing, 1982).

23 Richard J. Needham, "Finding it out for yourself," The Globe and Mail, 14 June 1968, 6.

24 Richard Needham's columns were posted on Toronto region high school bulletin boards and regularly discussed in senior English classes. He was a peculiar anti-hero for teenagers, but revered by my more 'hip' English teachers at Thornhill Secondary School from 1966 to 1968. 
25 Andrew Szende, “Our Schools: The Way They Are," The Toronto Daily Star, 15 June $1968,8$.

26 Eric W. Ricker, "Teachers, Trustees and Schools: The Politics of Education in Ontario, 1945-1975," PhD Thesis, University of Toronto, 1981, 475-476.

27 Ricker, "Teachers, Trustees and Schools," 304-305, and 612-613.

28 "The Aims Committee: Too Heavily Elementary?, " InterCom Special Issue/Hall-Dennis Report (November 1968), 1. See also Ricker, 304, and 485-486.

29 Dennis Gruending, Emmett Hall: Establishment Radical (Toronto: Macmillan, 1985), 114-115; and a news story based upon an Interview with Lloyd Dennis in The Toronto Daily Star, 12 June 1969, 8.

30 Barrie Zwicker and Barrie Doyle, "Changes in Education in Full-Swing," The Toronto Daily Star, 12 June 1969, 8.

31 R.W. Nicholls, Letter to the Editor, The Globe and Mail, 15 June, 1968, 6.

32 Ralph Blackmore, Letter to the Editor, The Globe and Mail, 19 June, 1968, 6.

33 D.J. Dooley, Letter to the Editor, The Globe and Mail, 20 June, 1968, 6. Dooley also referenced an earlier warning issued by J.M. Robson, Professor, Victoria College, University of Toronto, in an Address to the Ontario Education Association, back in March 1968.

34 Ontario Institute for Studies in Education Library, J.H. R. Morgan, "Living and Learning," Speaking Notes, Teach-In, Ontario College of Education, 11 January 1969 (Vertical file: Hall-Dennis Report)

35 John M. Robson, "First Day of School: Why Johnny will do more Living than Learning," The Toronto Daily Star, 2 September 1969.

36 Geoffrey Milburn, "The Historian and the Hall-Dennis Report," Reactions to HallDennis: A Collection of Comments from the Point of View of the Secondary School (Toronto: Holt, Rinehart and Winston, 1969), 10 and 12-16.

37 Norman Sheffe, "A Teacher Looks at the Hall-Dennis Report," Reactions to the HallDennis Report, 24-7.

38 OISE Library, Ontario Teachers Federation, "Survey of Teachers' Professional Opinions, 1969" (Vertical file: Hall-Dennis Report); and the executive summary in "Focus on the Hall-Dennis Report," Orbit (December, 1969).

39 See George Martell, ed., The Politics of the Public School (Halifax: Formac Publishing, 1974), Introduction, and articles from This Magazine is About Schools.

40 Trueman Interviews, 16 September and 25 September 2010.

41 Gruending, Emmett Hall, 115; and The Toronto Daily Star, 12 June 1969, 8. See also Lloyd Dennis, "Living and Learning: After Sixteen Months," Orbit, Preliminary Issue, No. 2 (December, 1969), 6.

42 Re-Thinking Education, Proceedings of the Conference on Living and Learning, April 17-19, 1969 (Toronto: OISE, 1969), 44-48.

43 William G. Davis, "The Ongoing Process of Educational Change," April 17, 1969, in Re-Thinking Education, 7-11 and Summary, 56.

44 James M. Paton, Re-Thinking Education, 56.

45 Daly, Education or Molasses?, 1-2.

46 Daly, Education or Molasses?, 8.

47 See Gidney, From Hope to Harris, 72.

48 Daly, Education or Molasses?, 20-21.

49 Daly, 4. See also the Hall-Dennis Report, 76, and Daly's reply, Education or Molasses?, 19

50 John Burns, "O.C.E. Teach-In Mixes Criticisms of Hall Dennis," The Globe and Mail, 13 January 1969.

51 Douglas Fisher and Harry Crowe, "Hall-Dennis Windy," Toronto Telegram, 26 September 1969.

52 The Fisher and Crowe column was nationally syndicated and appeared, for example, in the Cape Breton Post, 16 October 1969. 
53 Fisher and Crowe, "Hall-Dennis Windy"; Vaughan, Aggressive in Pursuit, 159; and Crittenden, "Slogans - Handle with Care," 36. See also Robin Barrow, The Canadian Curriculum: A Personal View (London: Althouse Press, University of Western Ontario, 1979)

54 R.W. B. Jackson, "The Hall-Dennis Report: A Personal Comment," Headmaster (Fall, 1968), 29-30; and Editorial, "An Educational Leap in the Dark," The Toronto Daily Star, 2 September 1972.

55 Daly, Education or Molasses?, 64; Crittenden, "Slogans - Handle with Care," 38; and John Ricker, "Reaction to the Ontario Ministry of Education Guidelines: History, Intermediate Division, Canadian Journal of History and Social Science, Vol. IX (Fall, 1973), 4.

56 Dormer Ellis and J. Rosaire Cloutier, OTF Reporter, No. 16 (February 1970), 6-9. See also W.G. Fleming, Ontario's Educative Society, Vol. III: Schools, Pupils and Teachers (Toronto: University of Toronto Press, 1971), 66-568.

57 John Kelsey, "Learning to Live with Hall-Dennis," The Globe and Mail, October 8, 1969. See also Burns, "O.C.E. Teach-In Mixes Criticisms of Hall-Dennis."

58 See W.G. Fleming, Education: Ontario's Preoccupation (Toronto: University of Toronto Press, 1972), 209-210, and 221. See also Warren Gerard, "Let Teachers, Pupils Select Subjects, Hall-Dennis Report Suggests," The Globe and Mail, 13 June 1968.

59 V.K. Gilbert, Let Each Become (Toronto: Guidance Centre, Faculty of Education, University of Toronto, 1972), 11, 13-36, 40-41, and 50-51.

60 See Fleming, Education: Ontario's Preoccupation, 211.

61 See Ontario, Department of Education, Circular H.H. 1, 1969-70; V.K. Gilbert, R.A. Martin, A.T. Sheehan, and B.C. Stewart, A Hard Act to Follow: Notes on Ontario School Law (Toronto; Guidance Centre, Faculty of Education, 1973), 32; and Fleming, Education: Ontario's Preoccupation. 212.

62 See J.W. Daly, "Responses to the Quebec Crisis," Canadian Forum ( April-May, 1971), 22-24. On Daly's immediate family, see Obituary, The Spectator (Hamilton), 29 November 1983.

63 James Daly, Book Review of W.G. Fleming, Education: Ontario's Preoccupation in The Canadian Historical Review, Vol. 55 (June 1974), 209-210.

64 See "John Muggeridge: Death of a Christian Gentleman," Catholic Insight, 1 January 2006; David Warren, Commentary, The Ottawa Citizen, 30 November 2005; and Paul Tuns, "John Muggeridge Remembered as a Man of National Significance," The Interim (January, 2006).

65 "John Muggeridge: Death of a Christian Gentleman." On Saint Athanasius and Arianism, see Encyclopedia Britannica (1979), Vol. I, 509.

66 See Anne Roche Muggeridge, The Desolate City: The Catholic Church in Ruins (Toronto; McClelland and Stewart, 1986); Robert Berard, Book Review of Anne Roche Muggeridge, The Desolate City, in CM Archive, Vol. 15, No. 2 (March 1987); and David Warren, "A Beautiful Soul," The Ottawa Citizen, 20 September 2010.

67 "John Muggeridge: Death of a Christian Gentleman."

68 Trueman Interview, 25 September 2010.

69 See Ricker, "Teachers, Trustees and Schools," 487-488.

70 See Walter Pitman, "The Big Blue Schoolhouse: The Davis Era in Ontario Education," in Douglas Myers, ed., The Failure of Educational Reform (Toronto: McClelland and Stewart, 1972), 148-149. See also The Toronto Daily Star, 2 September 1972.

71 Harold M. Nason, "Developments in Education in Nova Scotia, Journal of Education (December, 1969), 3-4.

72 Russell Hunt, "Pruning the Public Schools," The Mysterious East (May-June 1971),m 31.

73 Judy Steed, "Crisis in the Schools," The Globe and Mail, 15 January 1983, 10. Professor John Trueman provided his pithy assessment in a Personal Interview, 16 September 
2010. See also Robert Neilsen, "A Report Card on Ontario's School System," The Toronto Star, 1 June 1974, A1 and A4.

74 See Coalition for Education Reform, Could Do Better: What's Wrong with Public Education in Ontario and How to Fix It ( Toronto: Coalition for Education Reform, 1994), 1-14 and 40-45. For news reports and letters clamouring for higher standards and blaming Hall-Dennis for the "downward spiral", see The Hamilton Spectator, 17 June 1992; The Globe and Mail, 21 June, 1993; The Toronto Star, Editorial, 27 January 1995; and The Hamilton Spectator, 9 March 2001. See also Gerald Caplan, "Tories in Thrall to Back-to-Basic School Ideologues," The Toronto Star, 19 September 1997.

75 Tami Paikin Nolan, "Was Hall-Dennis Report 'Psychedelic Propaganda?" The Hamilton Spectator, 21 April 1993. 